\title{
Tahap Preliminary Research Pengembangan Perangkat Pembelajaran Berbasis Penemuan Terbimbing UNTUK MeningKatKan Kemampuan Komunikasi Matematis PeSERTa DIDIK KELAS VIII MTS/SMP
}

\author{
The Stage of Preliminary ReSEarch DeVelopment BaSEd on EnhanCing \\ STUDENTS Mathematical CoMmunication SKILl In Class VIII MTS / SMP
}

\author{
Muthia Rahmi ${ }^{1}$, Yerizon $^{2}$ dan Edwin Musdi $^{3}$ \\ ${ }^{1}$ Mahasiswa Pascasarjana FMIPA, Universitas Negeri Padang \\ Padang, Sumatera Barat, Indonesia \\ rahmimuthia.90@gmail.com \\ 2,3 Staf Pengajar Pascasarjana FMIPA, Universitas Negeri Padang \\ Padang, Sumatera Barat, Indonesia
}

\begin{abstract}
Abstrak
Berdasarkan hasil analisis pendahuluan yang dilaksanakan di MTs Lembah Gumanti, diperoleh informasi bahwa kemampuan komunikasi matematis peserta didik belum tercapai secara optimal. Salah satu faktor penyebabnya adalah belum tersedianya perangkat pembelajaran yang dapat memfasilitasi peserta didik untuk meningkatkan kemampuan komunikasi matematis peserta didik. Hal tersebutlah yang mendasari untuk melakukan pengembangan perangkat pembelajaran matematika berupa Rencana Pelaksanan Pembelajaran (RPP) dan Lembar Kerja Peserta didik (LKPD) berbasis Penemuan terbimbing yang memberikan kesempatan kepada peserta didik untuk dapat menemukan sendiri konsep dari materi yang dipelajari sehingga peserta didik dapat mengkomunikasikan pengetahuan tersebut baik secara lisan maupun tulisan. Data dikumpulkan melalui observasi, dokumentasi, angket, wawancara, dan tes kemampuan komukasi matematis. Subjek penelitian adalah peserta didik kelas VIII MTs/SMP Lembah Gumanti. Jenis penelitian ini adalah penelitian pengembangan menggunakan model Plomp yang terdiri dari fase preliminary research berupa analisis kebutuhan, analisis peserta didik, analisis kurikulum, dan analisis konsep. Pada fase prototype dilakukan perancangan produk yaitu RPP dan LKPD berbasis penemuan terbimbing, kemudian dilakukan evaluasi formatif untuk menentukan kevalidan dan kepraktisan produk. Pada fase asessment dilakukan penilaian uji praktikalitas dan uji efektivitas. Tujuan dari penelitian ini diharapkan dapat memperoleh perangkat pembelajaran matematika berbasis penemuan terbimbing untuk kelas VIII MTs/SMP yang memiliki karakteristik valid, praktis dan efektif.

Kata Kunci: Kemampuan Komunikasi Matematis, Penemuan Terbimbing, Model Plomp.
\end{abstract}

\begin{abstract}
Berdasarkan hasil analisis pendahuluan yang dilaksanakan di MTs Lembah Gumanti, diperoleh informasi bahwa kemampuan komunikasi matematis peserta didik belum tercapai secara optimal. Salah satu faktor penyebabnya adalah belum tersedianya perangkat pembelajaran yang dapat memfasilitasi peserta didik untuk meningkatkan kemampuan komunikasi matematis peserta didik. Hal tersebutlah yang mendasari untuk melakukan pengembangan perangkat
\end{abstract}


pembelajaran matematika berupa Rencana Pelaksanan Pembelajaran (RPP) dan Lembar Kerja Peserta didik (LKPD) berbasis Penemuan terbimbing yang memberikan kesempatan kepada peserta didik untuk dapat menemukan sendiri konsep dari materi yang dipelajari sehingga peserta didik dapat mengkomunikasikan pengetahuan tersebut baik secara lisan maupun tulisan. Data dikumpulkan melalui observasi, dokumentasi, angket, wawancara, dan tes kemampuan komukasi matematis. Subjek penelitian adalah peserta didik kelas VIII MTs/SMP Lembah Gumanti. Jenis penelitian ini adalah penelitian pengembangan menggunakan model Plomp yang terdiri dari fase preliminary research berupa analisis kebutuhan, analisis peserta didik, analisis kurikulum, dan analisis konsep. Pada fase prototype dilakukan perancangan produk yaitu RPP dan LKPD berbasis penemuan terbimbing, kemudian dilakukan evaluasi formatif untuk menentukan kevalidan dan kepraktisan produk. Pada fase asessment dilakukan penilaian uji praktikalitas dan uji efektivitas. Tujuan dari penelitian ini diharapkan dapat memperoleh perangkat pembelajaran matematika berbasis penemuan terbimbing untuk kelas VIII MTs/SMP yang memiliki karakteristik valid, praktis dan efektif.

Keyword: Mathematical Communication Skill, Guided Discovery, Model Plomp.

\section{Pendahuluan}

Matematika adalah salah satu ilmu dasar yang memegang peranan penting dalam pembentukan pola pikir peserta didik. Pola pikir tersebut dapat terbentuk dalam pembelajaran matematika apabila setiap peserta didik mampu memahami matematika dengan baik. Selain itu, matematika juga memiliki peranan yang sangat penting dalam perkembangan ilmu pengetahuan dan teknologi. Oleh sebab itu, untuk menguasai dan menciptakan teknologi diperlukan penguasaan matematika yang kuat sejak dini. Mata pelajaran matematika perlu diberikan kepada peserta didik dengan kemampuan berfikir logis, sistematis, kritis dan kreatif serta kemampuan bekerja sama.

Mengingat pentingnya matematika dalam perkembangan ilmu pengetahuan dan teknologi berbagai upaya telah dicoba diusahakan oleh pemerintah, mulai dari diadakannya penyempurnaan kurikulum, diadakannya pelatihan-pelatihan bagi guru bidang studi matematika, melengkapi sarana dan prasarana, dan menyediakan buku pelajaran. Yang menjadi perhatian saat sekarang ini adalah upaya pemerintah dalam meningkatkan mutu pendidikan dengan cara penyempurnaan kurukulum dari Kurikulum Tingkat Satuan Pendidikan (KTSP) menjadi kurikulum 2013. Kurikulum 2013 disiapkan agar bangsa Indonesia memiliki kemampuan hidup sebagai pribadi dan warga negara yang beriman, produktif, kreatif, inovatif, dan afektif berdasarkan Permendikbud nomor 68 tahun 2013.

Beberapa tujuan pembelajaran matematika dijelaskan dalam Peraturan Menteri Pendidikan dan Kebudayaan Republik Indonesia Nomor 58 tahun 2014 adalah : 1). Mengkomunikasikan gagasan, penalaran serta mampu menyusun bukti matematika dengan menggunakan kalimat lengkap, simbol, tabel, diagram, atau media lain untuk memperjelas keadaan atau masalah. 2). Memiliki sikap menghargai kegunaan matematika dalam kehidupan, yaitu memiliki rasa ingin tahu, 
perhatian, dan minat dalam mempelajari matematika, serta sikap ulet dan diri dalam pemecahan masalah.

Berdasarkan tujuan pembelajaran matematika yang dijelasakan dalam Peraturan Menteri Pendidikan dan Kebudayaan Republik Indonesia Nomor 58 tahun 2014, salah satu kemampuan yang harus dikuasai peserta didik adalah kemampuan komunikasi matematis. Kemampuan komunikasi matematika salah satu terpenting dalam proses pembelajaran matematika, akibatnya sangat perlu dikembangkan terhadap peserta didik. Hal ini senada dengan yang diungkapkan Mahmudi (2009). bahwa komunikasi matematika merupakan salah satu standar kompetensi kelulusan dalam bidang matematika peserta didik sekolah dari pendidikan dasar sampai menengah. Kemampuan komunikasi matematika peserta didik sangat perlu diperhatikan, disamping standar kelulusan, komunikasi matematika merupakan cara yang digunakan peserta didik untuk menyatakan suatu gagasan atau ide matematika baik dengan lisan maupun tulisan yang dapat menggambarkan proses berfikir seseorang.

Komunikasi matematis adalah peserta didik mampu menyatakan dan menafsirkan gagasan matematika secara lisan, tertulis, atau mendemonstrasikan (Shadiq, 2016). Membuat model situasi atau persoalan menggunakan metode oral, tertulis, konkrit, grafik, dan aljabar. Menggunakan keahlian membaca, menulis, dan menelaah untuk menginterpretasikan dan mengevaluasi ide-ide, simbol, istilah, serta informasi matematika dan merespon suatu pernyataan persoalan dalam bentuk pendapat.

Berdasarkan hasil wawancara dengan beberapa orang peserta didik dan beberapa orang guru di MTsN Lembah Gumanti dan MTs Tanjung Balik, diperoleh informasi bahwa peserta didik masih kesulitan saat menjawab soal yang berbentuk narasi. Peserta didik kesulitan saat menafsirkan dan memahami permasalahan dalam bentuk matematika maupun gambar.B eberapa peserta didik bisa menyelesaikan soal yang diberikan namun mereka kesulitan saat diminta guru untuk memperentasikan hasil jawabannya didepan kelas. Selain itu peserta didik bisa menyelesaikan soal dengan hasil yang benar namun langkah-langkah penyelesainannya tidak terstruktur dengan baik ini merupakan akibat dari kurang terlatihnya peserta didik dalam mengkomunikasaikan matematika dalam bentuk lisan maupun tulisan. Berdasarkan informasi yang diperoleh dari guru, perangkat pembelajaran yang digunakan guru terdiri dari Rencana Pelaksanaan Pembelajaran (RPP), Lembar Kerja Peserta Didik (LKPD) dan buku paket yang ditemui di lapangan masih belum sepenuhnya membantu peserta didik dalam proses pembelajaran.

Berdasarkan analisis terhadap RPP, kegiatan yang telah dirancang oleh guru sudah baik, namun kegiatan yang dipaparkan didalam RPP belum membantu 
peserta didik untuk menemukan konsep dari materi yang dipelajari secara langsung. Pada langkah-langkah kegiatan inti terlihat gambaran, guru cendrung langsung memberikan penjelasan materi inti kepada peserta didik, memberikan rumus-rumus, memberikan contoh soal dan langsung kepada latihan. Biasanya soal yang diberikan guru yang bersifat rutin, sehingga peserta didik mengalami kesulitan dalam menyelesaikan soal-soal yang bervariasi khususnya soal-soal yang berhubungan dengan kemampuan komunikasi.

Saat peserta didik kesulitan menjawab soal yang diberikan, maka peserta didik cendrung menunggu jawaban dari guru sehingga peserta didik hanya menerima dan kurang terlatih dalam mengkontruksi pengetahunanya sendiri dalam menyelesaikan soal-soal yang dipelajari. Hal inilah yang menunjukkan kurang aktifnya peserta didik sehingga menyebabkan hasil belajar yang rendah yang terbukti dari nilai hasil belajar matematika yang masih dibawah kriteria Ketuntasan Minimal (KKM) yaitu 80.

Upaya guru dalam mengaktifkan peserta didik dalam proses pembelajaran sudah terlihat dari menyediakan bahan ajar berupa LKPD, namun sayangnya LKPD yang disediakan bukan hasil dari pengembangan guru tersebut. LKPD yang digunakan saat ini masih LKPD yang dikembangkan guru matematika lain yang dibeli dipercetakan. Hal ini sangat berpengaruh karna tidak semua isi dalam LKPD sesuai dengan karakteristik peserta didik. Dari analisis terhadap LKPD, terlihat paparan rumus dari topik materi tanpa adanya langkah-langkah yang mendorong peserta didik untuk menenukan konsep dari materi tersebut sehingga peserta didik kurang bisa mengkontruksi pengetahuannya sendiri.

Berdasarkan analisis yang dilakukan terhadap LKPD, terlihat penyajian materi pada langsung saja pada inti materi. Peserta didik langsung diberikan konsep dari materi pelajaran. Di dalam LKPD belum didukung dengan kegiatan yang melibatkan peserta didik secara aktif dalam melakukan penemuan-penemuan guna membangun konsep terhadap materi yang dipelajari. Kurangnya keterlibatan peserta didik dalam membangun pengetahuannya sendiri megakibatkan peserta didik cendrung menghafal rumus dan peserta didik mudah lupa terhadap rumus tersebut. Hal ini bertolak belakang dengan tujuan awal LKPD digunakan.

Terlepas dari permasalah di atas, seharusnya kita tidak bisa hanya menyalahkan guru dan peserta didik jika suatu proses pembelajaran tidak berjalan dengan lancar, untuk mengatasi permasalahan yang terjadi pada pembelajaran matematika dikelas, diperlukan suatu usaha dalam memilih model dan bahan ajar dalam pembelajaran. Guru dituntut lebih kreatif, inovatif, menempatkan peserta didik tidak hanya sebagai objek belajar tetapi juga sebagai subjek belajar dan pada akhirnya bermuara pada proses pembelajaran yang menyenangkan, bergembira dan aktif. 
Berdasarkan masalah yang dipaparkan diatas maka perlu dikembangkan suatu bahan ajar matematika, yaitu bahan ajar yang berbasis penemuan terbimbing yang dapat menfasilitasi peserta didik dan ibu bapak untuk mengkontruksi pengetahuannya sendiri. Dengan adanya bahan ajar bebasis penemuan terbimbing ini diharapkan dapat meningkatkan kemampuan komunikasi matematis peserta didik dan kemampuan peserta didik dalam menemukan prinsip matematika. Model penemuan terbimbing adalah suatu cara penyampaian topik matematika sedemikian rupa sehingga dalam proses belajar memungkinkan peserta didik menemukan sendiri polapola atau struktur-struktur matematika melalui serentetan pengalaman belajar yang lampau dan tidak lepas dari pengawasan serta bimbingan guru (Risnawati,2008).

Sesuai dengan pendapat Suherman (2001). "Pada penemuan terbimbing guru memberikan petunjuk, arahan-arahan, pernyataan-pernyataan atau dialog sampai pada suatu kesimpulan tentang materi yang diajarkan, bimbingan diberikan guru tergantung dengan kemampuan peserta didik dan topik yang diajarkan".

Dapat disimpulkan penemuan terbimbing adalah suatu model pembelajaran yang membantu peserta didik dalam mengontruksi pengetahuannya sendiri melalui serentetan kegiatan pelajaran, dimanan guru bertugas memberikan bantuan berupa petunjuk, arahan-arahan, pernyataan-pernyataan atau dialog selama proses pembelajaran berlangsung.

Langkah-langkah model pembelajaran berbasis penemuan berbasis terbimbing yaitu : (1) Guru Merumuskan masalah yang akan diberikan kepada peserta didik dengan data secukupnya, (2) Dari data yang diberikan guru, peserta didik menyusun, memproses, mengorganisir, dan menganalisis data tersebut, (3) Peserta didik menyusun konjektur (prakiraan) dari hasil analisis yang dilakukannya, (4) Konjektur yang telah dibuat oleh peserta didik tersebut di atas diperiksa oleh guru, (5) Apabila telah diperoleh kepastian tentang kebenaran konjektur tersebut, maka verbalisasi konjektur sebaiknya diarahkan juga kepada peserta didik untuk menyusunnya, (6) Sesudah peserta didik menemukan apa yang dicari, hendaknya guru menyediakan soal latihan atau soal tambahan untuk memeriksa apakah hasil penemuan itu benar. Model pembelajaran berbasis penemuan terbimbing merupakan salah satu model pembelajaran yang disarankan untuk diterapkan dalam proses pembelajaran berdasarkan kurikulum 2013.

Pembelajaran penemuan terbimbing dapat dilakukan secara individual maupun secara diskusi kelompok. Tetapi pada penelitian ini akan difokuskan secara berkelompok. Diskusi kelompok memungkinkan peserta didik berlatih untuk mengekspresikan pemahaman, memverbalkan proses berpikir, dan mengklarifikasi pemahaman atau 
ketidakpahaman mereka. Dalam proses diskusi kelompok, akan terjadi pertukaran ide dan pemikiran antarpeserta didik. Hal ini akan memberikan kesempatan kepada peserta didik untuk membangun pemahaman matematiknya. Percakapan antarpeserta didik dan 2008 juga akan mendorong atau memperkuat pemahaman yang mendalam akan konsepkonsep matematika. Ketika peserta didik berpikir, merespon, berdiskusi, mengelaborasi, menulis, membaca, mendengarkan, dan menemukan konsepkonsep matematika, mereka mempunyai berbagai keuntungan, yaitu berkomunikasi untuk belajar matematika dan belajar untuk berkomunikasi secara matematis.

Bahan ajar yang akan dikembangkan akan berbentuk LKPD. LKPD berisi langkahlangkah kegiatan yang harus dilakukan oleh peserta didik untuk menemukan konsep pembelajaran dan latihan-latihan. Sebagaimana yang dinyatakan oleh Depdiknas (2008) bahwa LKPD berisi tugas yang harus dikerjakan peserta didik, biasanya berupa petunjuk dan langkahlangkah untuk menyelesaikan suatu tugas. LKPD berisi sekumpulan kegiatan, masalah atau soal yang akan dikerjakan peserta didik selama pembelajaran. Lembar kegiatan ini juga bisa berisi materi maupun langkah-langkah untuk menyelesaikan tugas. LKPD dapat membantu peserta didik untuk terlatih dalam belajar mandiri serta mengasah kemampuan berfikir kreatif dan kritis dalam menyelesaikan masalah.
LKPD akan berisi pertanyaanpertanyaan yang harus dijawab peserta didik, dengan adanya langkah-langkah penemuan terbimbing peserta didik mempunyai kesempatan untuk mengeksplor kemampuannya dalam menyajikan pernyataan matematika secara lisan, tertulis, gambar, dan diagram, mengajukan dugaan (conjecture), melakukan manipulasi matematika, dan menarik kesimpulan, menyusun bukti, memberikan alasan atau bukti terhadap beberapa solusi. Pada akhirnya peserta didik akan bisa mengkomunikasikan gagasannya yang bermuara pada ditemukannya konsep materi yang sedang dipelajari. Bantuan guru dalam penerapan metode berbasis penemuan terbimbing ini sangat dibutuhkan dalam mengarahkan peserta didik dan membimbing peserta didik dalam melakukan penemuanpenemuan.

Selain LKPD berbasis penemuan terbimbing untuk lebih efektifnya pembelajaran maka akan disertai dengan Rencana Pelaksanaan Pembelajaran (RPP). RPP merupakan perangkat pembelajaran yang sangat penting dalam pembelajaran, karena semua kegitan guru dan peserta didik telah direncanakan didalam RPP. RPP yang akan dibuat tentunya sesuai dengan konsep berbasis penemuan terbimbing. RPP dibuat sebagai pedoman guru agar kegiatan yang akan dilakukan guru dan peserta didik dalam kelas lebih terarah dan kegiatan pembelajaran akan terencana dengan matang. 


\section{MetOde}

Jenis penelitian ini adalah penelitian pengembangan dengan menggunakan model Plomp, model ini terdiri dari tiga fase, yaitu fase investigasi awal (preliminary research), fase pengembangan atau pembuatan prototipe (prototyping stage), dan fase penilaian (assessment stage) (Plomp \& Nieveen, 2013). Fase investigasi awal (preliminary research) terdiri dari analisis kebutuhan, analisis kurikulum, analisis konsep dan analisis peserta didik. Analisis kebutuhan dibutuhkan untuk mendapatkan informasi mengenai permasalahan dalam bidang pendidikan (terdapat kesenjangan di antara situasi yang ada dengan yang diharapkan). Tujuan dari fase ini adalah, untuk memperoleh informasi mengenai permasalahan yang ada dan kemungkinan membutuhkan perbaikan dan inovasi. Pengumpulan informasi dilakukan dengan observasi proses pembelajaran dikelas dan wawancara dengan guru mata pelajaran.

Tahap analisis peserta didik dilakukan untuk mengetahui bagaimana karakter peserta didik. Karakter ini antara lain bagaimana pendapat atau kesulitan peserta didik saat belajar matematika, mengetahui bagaimana kemampuan akademis, mengetahui bagaimana bentuk bahan ajar yang disukai pesrta didik. Untuk pengumpulan informasi dilakukan dengan wawancara dengan guru dan membagikan angket kepada peserta didik.

Pada analisis kurikulum akan dilakukan analisis kurikulum yang digunakan disekolah kususnya untuk bidang studi matematika kelas VIII. Selanjutnya pada tahap investigasi awal ini dilakukan dengan analisis konsep yang bertujuan untuk merinci dan menyusun mteri apa saja yang akan dipelajari peserta didik dengan menerapkan metode penemuan terbimbing.

Pada prototyping stage, pembuatan prototipe ini dilakukan evaluasi formatif. Fase pengembangan atau pembuatan prototype (prototyping stage) terdiri atas prototype 1, yaitu evaluasi diri sendiri (self evaluation); prototype 2 yaitu expert review; prototype 3 yaitu evaluasi satusatu; prototype 4, yaitu evaluasi kelompok kecil. Validasi perangkat dilakukan oleh tiga orang dosen Matematika, satu orang dosen Bahasa Indonesia, dan satu orang dosen Teknologi Pendidikan.

Pada fase penilaian (assessment stage), dilakukan uji lapangan pada kelas VIII MTsN Lembah Gumanti untuk melihat praktikalitas dan efektivitas. Data penelitian dikumpulkan melalui lembar self evaluation, lembar validasi, lembar observasi dan pedoman wawancara, lembar angket respon guru dan peserta didik, lembar observasi keterlaksanaan RPP, dan tes kemampuan komunikasi.

\section{Hasil dan Pembahasan}

Berdasarkan analisis pendahuluan yang telah dilakukan di MTsN Lembah Gumanti dan MTs Nurul IImi, tahap analisis kebutuhan dilakukan pengumpulan informasi yang unuk mengetahui permasalahan yang terdapat dalam proses pembelajaran matematika disekolah. 
Pengumpulan informasi dilakukan dengan mengobservasi guru yang sedang mengajar dan memperhatikan aktivitas peserta didik. Berdasarkan observasi yang dilakukan terlihat bahwa proses pembelajaran belum terlaksana secara optimal. Guru terlihat masih mendominasi kegiatan dikelas. Peserta didik masih kesulitan untuk mengungkapkan apa yang ingin disampaikan saat guru memberikan pertanyaan.

Berdasarkan wawancara dengan beberapa orang guru, ada guru yang tidak menggunakan LKPD dengan alasan masih belum sempat membuat LKPD sendiri dan hanya menggandalkan buku cetak untuk menyempaikan materi kepada peserta didik. Sedangkan guru yang menggunakan LKPD menyatakan LKPD yang dipergunakan oleh peserta didik belum optimal membantu peserta didik untuk memahami materi yang diajarkan. Ini diakibatkan didalam LKPD belum tersedianya langkah-langkah kegiatan yang akan membantu peserta didik untuk memperoleh pengetahuannya sendiri. Berdasarkan wawancara diperoleh informasi bahwa kemampuan peserta didik beragam.

Tahap selanjutkan utnuk mengetahui karakter peserta didik selain melalui wawancara dengan peserta didik juga dilakukan dengan pembagian angket. Guru mengatakan bahwa kemampuan akademis peserta didik masih rendah ini terbukti dari ulangan harian yang diakadan dari 36 siswa yang memenuhi nilai diatas KKM hanya 8 sampaii 15 orang saja. Peserta didik menyatakan bahwa banyak yang menyatakan matematika pelajaran yang tidak menyenangkan. LKPD yang digunakan kurang menarik karna warna LKPD seperti kertas koran. Soal-soal yang terdapat dalam LKPD sangat sulit utuk dikerjakan.

Pada tahap analisis kurikulum dilakukan telaah terhadap Kurikulum 2013 untuk mata pelajaran matematika kelas VIII SMP. Menganalisis kurikulum bertujuan untuk mengetahui apakah materi yang diajarkan sudah sesuai dengan kompetensi yang diharapkan. Analisis kurikulum difokuskan pada analisis KI dan KD. Analisis kurikulum bertujuan sebagai pedoman dalam pengembangan perangkat pembelajaran matematika berbasis penemuan terbimbing untuk peserta didik kelas VIII MTs/SMP. Hasil analisis KI dan KD yang terdapat pada standar isi dijabarkan menjadi indikator-indikator pencapaian pembelajaran. Berdasarkan hasil analisis silabus mata pelajaran matematika kelas VIII SMP. Berdasarkan analisis tersebut diperoleh kesimpulan bahwa materi yang akan digunakan dalam rangka pengembangan perangkat pembelajaran yaitu seluruh materi matematika kelas VIII MTs/SMP. Diantara materi tersebut adalah koordinat cartesius, aljabar, relasi dan fungsi, persamaan garis lurus, teorema pytagoras dan statistika.

Selanjutkan dilakukan analisis konsep untuk menentukan isi dan materi pelajaran yang dibutuhkan dalam pengembangan perangkat pembelajaran matematika berbasis penemuan 
terbimbing. Adapun konsep utamanya adalah semua materi yang terdapat dalam pokok bahasan yang disajikan pada perangkat pembelajaran berbasis penemuan terbimbing.

\section{Penutup}

Penelitian ini merupakan penelitian pengembangan yang menghasilkan perangkat pembelajaran berbasis penemuan terbimbing berupa RPP dan LKPD yang valid, praktis dan efektif untuk meningkatkan kemampuan komunikasi matematis peserta didik kelas kelas VIII MTs/SMP. Proses pengembangan perangkat pembelajaran berbasis penemuan terbimbing untuk peserta didik kelas VIII MTs/SMP dilaksanakan dengan model pengembangan Plomp yang terdiri atas tiga fase yaitu fase investigasi awal, fase pengembangan dan fase penilaian. Pada fase pendahuluan dilaksanakan analisis kebutuhan, analisis kurikulum, analisis peserta didik dan analisis konsep sebagai langkah awal untuk melakukan penelitian pengembangan perangkat pembelajaran. Hasil pada analisis kebutuhan berupa karakteristik perangkat pembelajaran yang diinginkan yaitu perangkat pembelajaran berbasis penemuan terbimbing berupa RPP dan LKPD. Hasil dari analisis kurikulum yaitu terdapat perubahan urutan KD dengan tujuan. Hasil dari analisis peserta didik adalah karakteristik perangkat pembelajaran yang disesuaikan dengan karakteristik peserta didik. Sedangkan hasil analisis konsep berupa urutan materi pelajaran yang dibutuhkan dalam pengembangan agar indikator pencapaian kompetensi bisa tercapai.

\section{DAfTAR Pustaka}

Depdiknas. 2008.2 Panduan Pengembangan Bahan Ajar. Jakarta: Direktorat Jenderal Manajemen Pendidikan Dasar dan Menengah.

Mahmudi, Ali. 2009. Komunikasi Dalam Pembelajaran Matematika. Jurnal MIPMIPA UNHALU. Diakses February 20, 2017, 12:31 AM

Plomp, $T$ dan N. Nieveen. (2013). Educational Design Research. Enshede: Netherlands Institute for Curriculum Development (SLO).

Risnawati. 2008. Strategi Pembelajaran Matematika. Pekanbaru: Suska Press Shadiq, Fadjar (2009). Kemahiran Matematika Yogyakarta: Depdiknas. Suherman, E. 2001. Startegi Pembelajaran Matematika Komtemporer. JICA. UPI Bandung. 
This page is intentionally left blank 